\title{
8-2011
}

\section{In Situ Analysis of Crack Propagation in Polymer Foams}

\author{
Elio E. Saenz \\ Florida Atlantic University, esaenz@fau.edu \\ Leif A. Carlsson \\ Florida Atlantic University \\ Anette M. Karlsson \\ Cleveland State University, a.karlsson@csuohio.edu
}

Follow this and additional works at: https://engagedscholarship.csuohio.edu/enme_facpub

Part of the Mechanical Engineering Commons

How does access to this work benefit you? Let us know!

Publisher's Statement

The final publication is available at Springer via http://dx.doi.org/10.1007/s10853-011-5491-y

\section{Original Citation}

Saenz, E. E., Carlsson, L. A., and Karlsson, A. M., 2011, "In Situ Analysis of Crack Propagation in Polymer Foams," Journal of Materials Science, 46(16) pp. 5487-5494.

This Article is brought to you for free and open access by the Mechanical Engineering Department at EngagedScholarship@CSU. It has been accepted for inclusion in Mechanical Engineering Faculty Publications by an authorized administrator of EngagedScholarship@CSU. For more information, please contact library.es@csuohio.edu. 


\title{
In situ analysis of crack propagation in polymer foams
}

\author{
Elio E. Saenz • Leif. A. Carlsson • Anette M. Karlsson
}

\begin{abstract}
This article presents an experimental study on the microscopic mechanisms associated with crack propagation in closed cell polymer foams. A brittle, slightly cross-linked polyvinyl chloride (PVC) foam of density $60 \mathrm{~kg} / \mathrm{m}^{3}$ and a ductile thermoplastic polyether sulfone (PES) foam of density $90 \mathrm{~kg} / \mathrm{m}^{3}$ were examined. The PVC and PES foams have similar cell size $(\approx 0.7 \mathrm{~mm})$ but the cell edges of the PES foam were much thicker than those in the PVC foam. Overall, it was observed that the elements of both foams fractured in an extensional mode. Crack propagation in the PVC foam was inter-cellular, where agglomerates of very small cells formed a region of weakness. Damaged cell walls were observed on both sides of the crack plane. For the PES foam, craze-like deformation bands were observed in the highly stretched region ahead of the blunted crack tip. Further ahead of the crack tip, highly stretched cells were observed. Fracture occurred predominantly through the center of the cells in the PES foam.
\end{abstract}

E. E. Saenz $(\bowtie) \cdot$ Leif. A. Carlsson

Department of Ocean and Mechanical Engineering, Florida

Atlantic University, Boca Raton, FL 33431, USA

e-mail: esaenz@fau.edu

URL: http://www.ome.fau.edu/

\author{
A. M. Karlsson \\ Department of Mechanical Engineering, University of Delaware, \\ Newark, DE 19716, USA \\ e-mail: karlsson@udel.edu \\ URL: http://www.me.udel.edu/
}

\section{Introduction}

Polymer foams, widely used as core materials in sandwich structures, are often extremely brittle (low $K_{\text {Ic }}$ values) and constitute a weak link of such structures. The toughness $\left(K_{\mathrm{Ic}}\right)$ is governed by the micro-mechanisms near the propagating crack. Polymer foams may be viewed as a structure rather than a homogeneous material. Foams are classified as "open" and "closed cells". Open cell foams are built up by cell edges ("struts"), while closed cell foams have membranes ("cell walls") connecting the cell edges. The membranes tend to be thin as surface tension draws much of the solid material into the cell edges when the foam is formed [1]. Most micro-mechanical analysis of crack propagation in foams is developed for open cell foams of simple 2D structures. Maiti et al. [1] developed a model for fracture of a 2D open cell foam (Fig. 1) (honeycomb) where the crack propagates an increment of one cell size when a strut near the crack tip fails in bending or by a combination of tension and bending. Failure of a strut is thus assumed to occur when the maximum bending stress in a strut reaches the tensile strength of the solid polymer. This model predicts that the fracture toughness of the foam, $K_{\mathrm{Ic}}$, is equal to $0.65 \sigma_{\mathrm{f}}(\pi \mathrm{l})^{1 / 2}\left(\rho^{*}\right)^{1.5}$ where $\sigma_{\mathrm{f}}$ is the fracture strength of the solid polymer, $\rho^{*}$ is the density ratio (relative density) of the foam and solid polymer $\left(\rho^{*}=\rho / \rho_{\mathrm{s}}\right)$, and 1 is the cell size. Maiti et al. [1] argued that the fracture process for closed cell foams is similar to the one in open cell foams, but with a different geometry scaling for the relative density. For closed cell foams, their model predicts $K_{\text {Ic }}$ being proportional to $\left(\rho^{*}\right)^{2}$. More recently, Choi and Sankar [2] presented a micro-mechanical method to predict the toughness, $K_{\mathrm{Ic}}$, for mode I, mode II, and mixed mode loadings of open cell foams. Similar to Maiti et al. [1], they also considered 2D honeycomb foam but with square cells 


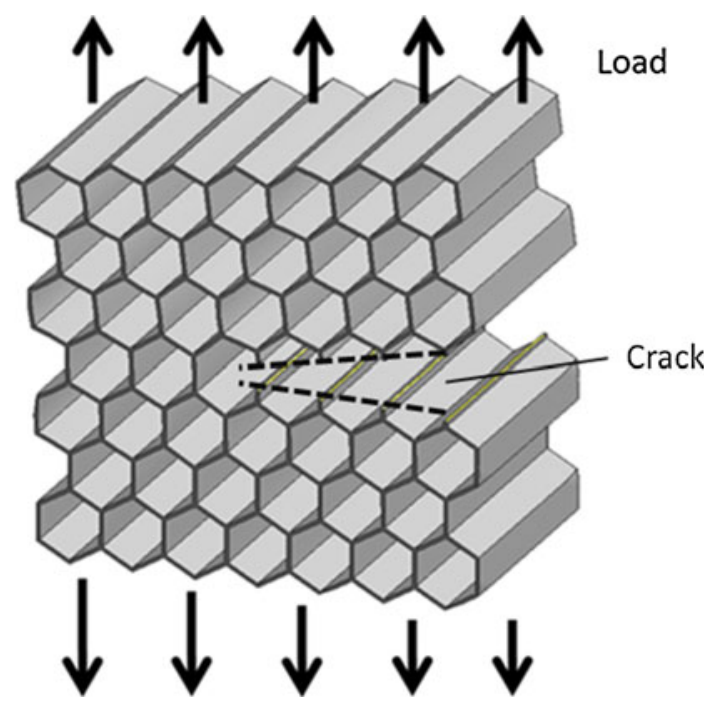

Fig. 1 Crack propagation in 2D open cell foam

rather than hexagonal (Fig. 1). Fracture was assumed to occur when the maximum tensile stress in the crack tip strut reached its ultimate value. The model utilizes a combination of an analytical solution for a crack in a homogeneous orthotropic material and a numerical finite element solution. For the two open cell foams they considered, $K_{\text {Ic }}$ was found to be proportional to the relative density $\left(\rho^{*}\right)$ to the powers of 1.045 and 0.788 .

Even though very useful models, the $2 \mathrm{D}$ idealizations proposed by Maiti et al. [1] and Choi and Sankar [2] may not accurately represent the fracture analysis. In fact, the randomness of the cell structure of actual foams provides more redundancy in the load path. Moreover, bending failure of the cell edges may not be the governing crack propagation mechanism. Zenkert and Bäcklund [3] conducted experimental fracture toughness testing on closed cell polyvinyl chloride (PVC) and polymethacrylimide (PMI) foams with densities ranging from 51 to $200 \mathrm{~kg} / \mathrm{m}^{3}$. They found that the fracture toughness of both foams scaled with relative density to the power of 1.1. Viana and Carlsson [4] tested PVC foams, and found that $K_{\text {Ic }}$ scales with density to the power of 1.04 , in close agreement with Zenkert and Bäcklund [3]. These experimental results strongly suggest that the closed cell PVC foams are not well represented by the idealized model discussed above. Moreover, the discrepancy suggests that the understanding of the failure evolution in PVC foams is not well understood and should be further explored.

Motz and Pippan [5] conducted an in situ fracture analysis on precracked closed cell ductile aluminum alloy foam specimens in a scanning electron microscope (SEM). Based on 3D full-field digital deformation measurements, they found no significant bending deformation of cell edges in the highly strained crack tip region. Crack growth was found to be controlled by stretching of the cell walls. They found that the crack propagated through the thinnest section of the cell edges of the aluminum by a tearing mechanism.

The current authors [6] recently conducted macroscopic fracture characterization of PVC foams and new thermoplastic polyether sulfone (PES) polymer foam. The PVC foams displayed brittle fracture response, while the PES foams displayed substantial ductility. The critical strain energy release rate, $G_{\mathrm{Ic}}$, for the H60 PVC and F90 PES foams examined herein are listed in Table 1, where it can be seen that $G_{\mathrm{Ic}}$ is significantly higher for PES foam than that of the PVC foam. The PVC foam displays similar initiation (from a razor sharpened tip) and propagation $G_{\text {Ic }}$ values as would be expected for a brittle polymer, while the $G_{\text {Ic }}$ for the PES foams, the initiation $G_{\text {Ic }}$ was much less than the propagation $G_{\mathrm{Ic}}$. It is of fundamental interest to examine experimentally the microscopical details of crack growth in closed cell cross-linked and thermoplastic polymer foams. Fracture tests here are conducted on precracked closed cell PVC and PES foam specimens inside a SEM.

\section{Experimental}

\section{Materials}

Two types of polymeric foams were examined in this study, PVC- and PES. Mechanical properties of solid PVC and PES polymers are listed in Table 2. A PVC foam of density $60 \mathrm{~kg} / \mathrm{m}^{3}$ (H60) and a PES foam of density $90 \mathrm{~kg} /$ $\mathrm{m}^{3}$ (F90) were examined. PVC foam is made by using three main components; an isocyanate (which cross-links the molecular chains of the PVC), a blowing agent (agent that starts the foaming process), and a stabilizer. The three components are mixed to form a plastisol which are then

Table 1 Critical energy release rates $G_{\mathrm{Ic}}\left(\mathrm{kJ} / \mathrm{m}^{2}\right)$ for PVC and PES foams [6]

\begin{tabular}{llll}
\hline Material & SENB & DCB & \\
\cline { 3 - 4 } & & Initiation & Propagation \\
\hline PVC (H60) & $0.24 \pm 0.01$ & $0.38 \pm 0.04$ & $0.33 \pm 0.04$ \\
PES (F90) & - & $0.72 \pm 0.08$ & $1.99 \pm 0.33$ \\
\hline
\end{tabular}

Table 2 Material properties of solid PVC and PES [10-12]

\begin{tabular}{lllll}
\hline & $\rho\left(\mathrm{Mg} / \mathrm{m}^{3}\right)$ & $E(\mathrm{GPa})$ & $\sigma_{\text {ys }}(\mathrm{MPa})$ & $G_{\mathrm{IC}}\left(\mathrm{kJ} / \mathrm{m}^{2}\right)$ \\
\hline PVC & 1.40 & 2.70 & 55.0 & 2.02 \\
PES & 1.37 & 2.70 & 90.0 & 2.60 \\
\hline
\end{tabular}


placed into a mold at an elevated temperature to start the reaction of the blowing agent. The foam is then allowed to cure to achieve its final slightly cross-linked character. Cross linking is known to reduce the ductility of polymers [7]. The mechanical properties for solid PVC listed in Table 2 may, therefore, not be representative for the solid material in PVC foams. The PES polymer is a transparent, amorphous, and ductile thermoplastic, similar to polycarbonate. To produce PES foams, solid PES particles are heated close to the melting point and then carbon dioxide is injected to commence the foaming process. In this case, the solid constituent of the PES foam remains unmodified. Hence, the material properties of solid PES listed in Table 2 should be representative for the solid polymer in the PES foam.

Microstructural characterization of the foams

The true density of the H60 and F90 foams was determined from weight and volume measurements according to ASTM D1622 [8], see further details in [6]. The cell size was determined according to ASTM D3576 [9] from specimens cut as shown in Fig. 2. Multiple reference lines were drawn at random to obtain statistical cell size data. The cell edge thickness was measured from SEM micrographs of cut foam specimens. It seems reasonable to assume that the exposed surface reveals mostly cell edges. For determination of the edge thickness, the thickness of ten edges was measured and the results averaged.

Tensile testing of foams

Tensile tests were conducted on the foams using $160 \mathrm{~mm}$ long dog-bone shaped specimens with a 25.4-mm long gage section with cross section of nominally $5 \times 12(\mathrm{~mm})$. Axial strain was measured using an extensometer attached to the gage section region. Care was taken to insure that failure did not occur at the contact point between the extensometer and the foam (specimens that failed at a contact point were not considered). The specimens were

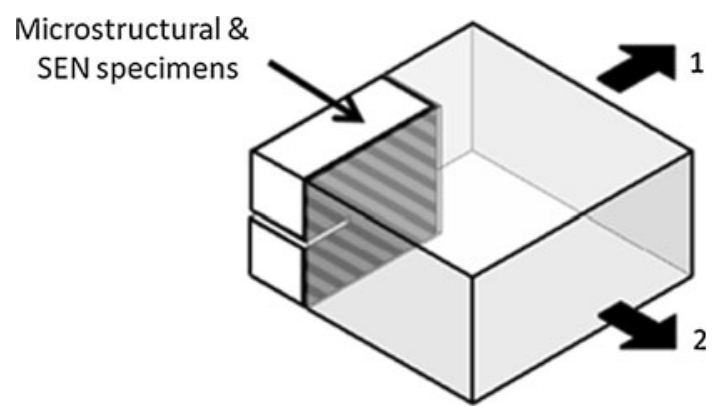

Fig. 2 Crack plane and plane of observation of microstructural and in situ fracture specimens

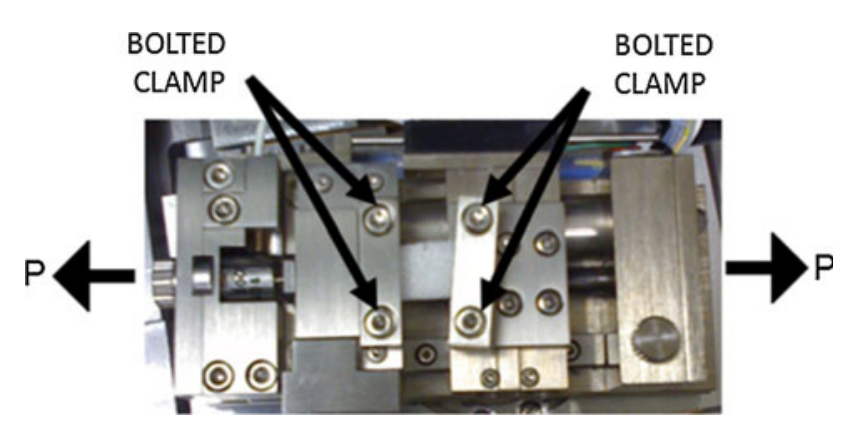

Fig. 3 Microtester with a cracked foam specimen (not clamped)

loaded at $1.27 \mathrm{~mm} / \mathrm{min}$ on a Tinius Olsen Load Cap using a $1.33 \mathrm{kN}$ load cell.

In situ fracture testing of cracked foam specimens

A DEBEN microtester (Fig. 3) accessory was used to perform in situ SEM fracture testing of the PVC and PES foams. Due to the limited space inside the SEM, small single edge notch (SEN) crack foam specimens, Fig. 4, of dimensions $30 \mathrm{~L} \times 12.7 \mathrm{~W}$ and $2.4 \mathrm{H}(\mathrm{mm})$, were cut from the foam panel as shown in Fig. 2 using a razor blade. A razor blade was also used to cut the initial crack to a nominal length $\left(a_{0}\right)$ of $2 \mathrm{~mm}$.

The microtester was equipped with a $200 \mathrm{~N}$ capacity load cell and an electric motor-driven lead screw (with user defined speed control) to load a specimen. Note that the load-displacement response of each in situ test specimen was recorded and used for reference only. Each test specimen was mounted in the microtester fixture and clamped with bolts tightened just enough to hold the specimen in place and prevent slipping during load application. The microtester was placed in a Quanta 200 SEM. The electron

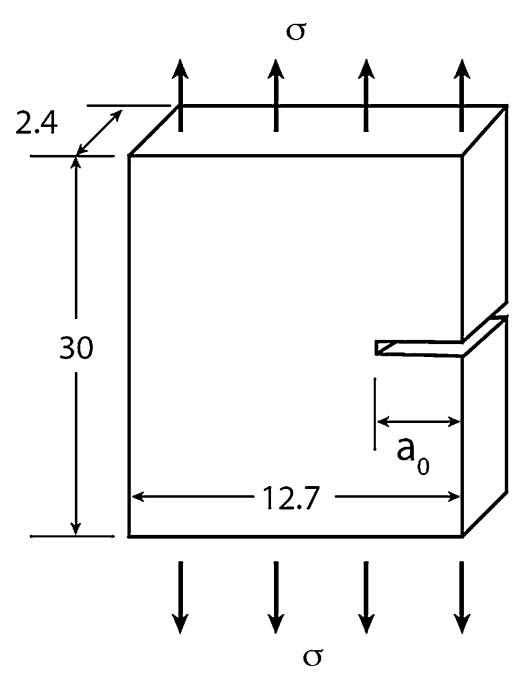

Fig. 4 Single edge notch tensile specimen dimensions. All dimensions are in $\mathrm{mm}$ 
voltage was set between 10 and $15 \mathrm{kV}$ and a small vacuum of 0.14 torr was used (higher vacuum lead to collapse of the foam cells). The in situ testing was done in steps at a rate of $0.5 \mathrm{~mm} / \mathrm{min}$. In situ testing of the foams was conducted at high and low magnifications. At high magnifications, $1500 \times$ for $\mathrm{PVC}$ and $4500 \times$ for PES, it was possible to examine the details of the crack propagation in the foam. An overall view of the crack propagation was obtained at a lower magnification, between $50 \times$ and $100 \times$. The overall view reveals deformation and failure of the foam cells in the region around the crack tip, also referred to as the fracture process zone, FPZ. The test program involved a total of four PVC and three PES replicate specimens.

\section{Results and discussion}

Density and microstructure of the foams

The measured densities of the foams are listed in Table 3. The densities are close to the nominal values targeted by the manufacturer. Figure 5 shows SEM micrographs of the unloaded and intact PVC and PES foams. Based on such micrographs, it is possible to determine the cell size and cell edge thickness. The results, summarized in Table 3, reveal that the cells in the two foams are of similar size, but

Table 3 Foam density and cell dimensions

\begin{tabular}{llll}
\hline Foam & $\begin{array}{l}\text { Density } \\
\left(\mathrm{kg} / \mathrm{m}^{3}\right)\end{array}$ & $\begin{array}{l}\text { Cell size } \\
(\mathrm{mm})\end{array}$ & $\begin{array}{l}\text { Cell edge thickness } \\
(\mu \mathrm{m})\end{array}$ \\
\hline PVC (H60) & $54.9 \pm 0.63$ & $0.67 \pm 0.06$ & $6.05 \pm 2.40$ \\
PES (F90) & $86.0 \pm 4.04$ & $0.73 \pm 0.03$ & $11.1 \pm 1.65$ \\
\hline
\end{tabular}
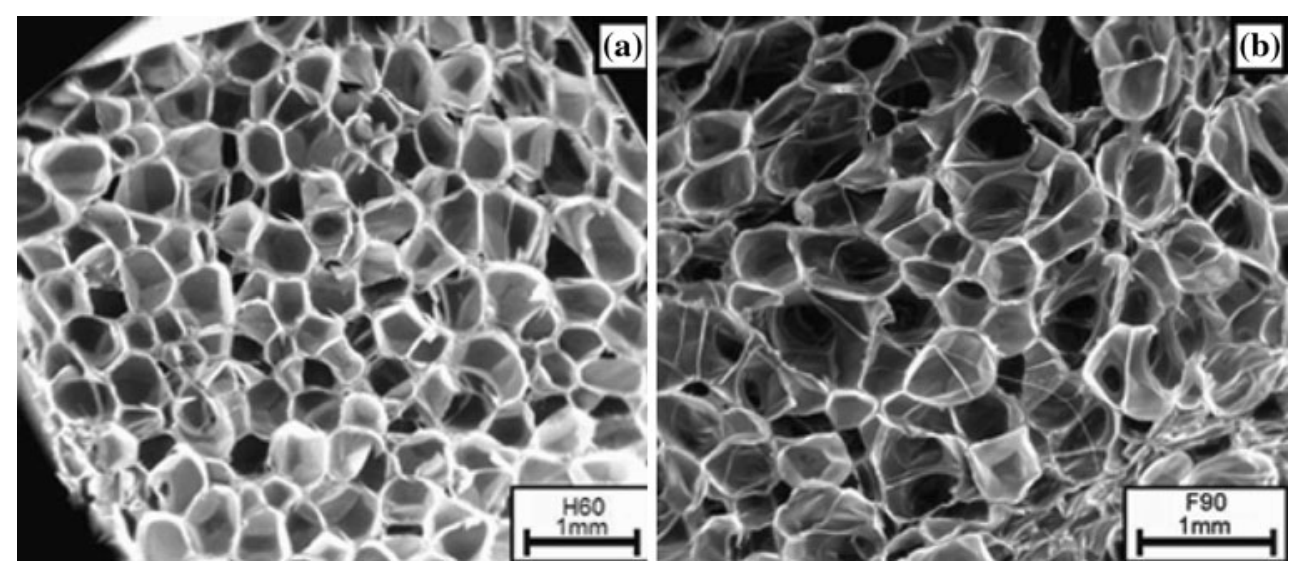

the edges in the PES foam are almost twice as thick as those in the PVC foam.

Tensile response

Figure 6 shows representative stress-strain curves recorded in tension for the PVC and PES foams. The PVC foam is stiffer and has higher ultimate strength than the PES foam at a lower apparent density due to the cross-linked nature of the polymer. However, the PVC behaves in a brittle manner whereas the PES foam displays a ductile behavior with an elongation of about $11 \%$. The measured tensile modulus and tensile strength of these foams are listed in Table 4.

In situ fracture response

To obtain direct information about the fracture mechanisms of the PVC and PES foams, in situ SEM studies on SEN specimens (Fig. 4) were performed. Figure 7 shows representative load-displacement records for the SEN PVC and PES specimens, and approximate indications of the load levels where the test was stopped and the specimens inspected (images were captured).

The SEM micrographs shown are not all from the same test specimen. The load drops in Fig. 7 were a combination of unobserved cell failures and stress relaxation as specimen loading was temporarily stopped.

Figures 8, 9, 10, 11 show the SEM micrographs for the PVC H60 foam specimens. The precrack is visualized by applying a small initial load $(\approx 1 \mathrm{~N})$, in Fig. 8a (shown at low magnification). Figure $8 \mathrm{~b}$ shows the precrack (in a different H60 specimen) at higher magnification. In both cases, the precrack is sharp and cuts through a cell wall. During the initial loading, to approximately $1.5 \mathrm{~N}$ in Fig. 8c, the precrack tip becomes slightly blunted. Figure 9a shows the crack tip (at low magnification) where the crack has propagated through a new cell wall. Upon further

Fig. 5 Microstructure of foams. a PVC (H60) and b PES (F90) 
Fig. 6 Tensile response of foams. a PVC (H60) and b PES (F90)
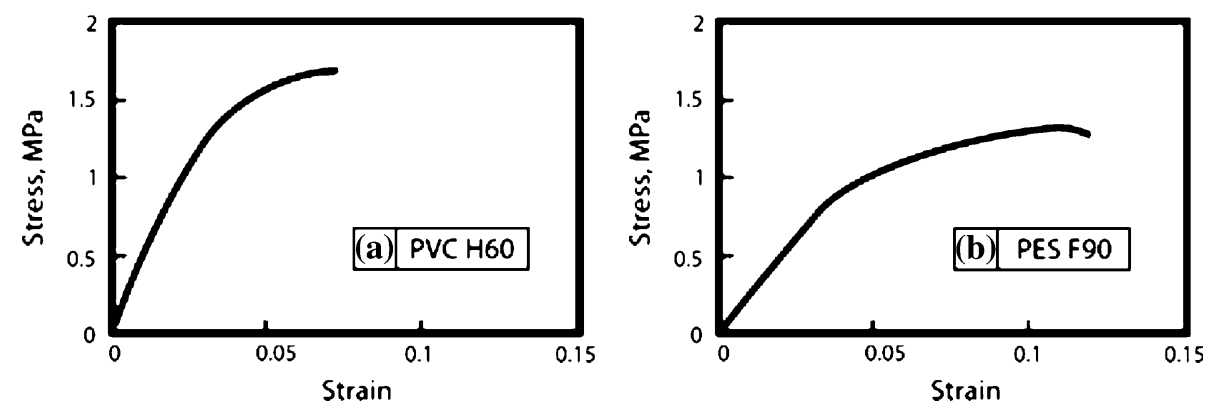

Table 4 Material properties in tension of PVC and PES foams

\begin{tabular}{lll}
\hline Material & Modulus (MPa) & Strength (MPa) \\
\hline PVC (H60) & $46.0 \pm 0.94$ & $1.64 \pm 0.08$ \\
PES (F90) & $22.7 \pm 4.01$ & $1.21 \pm 0.09$ \\
\hline
\end{tabular}
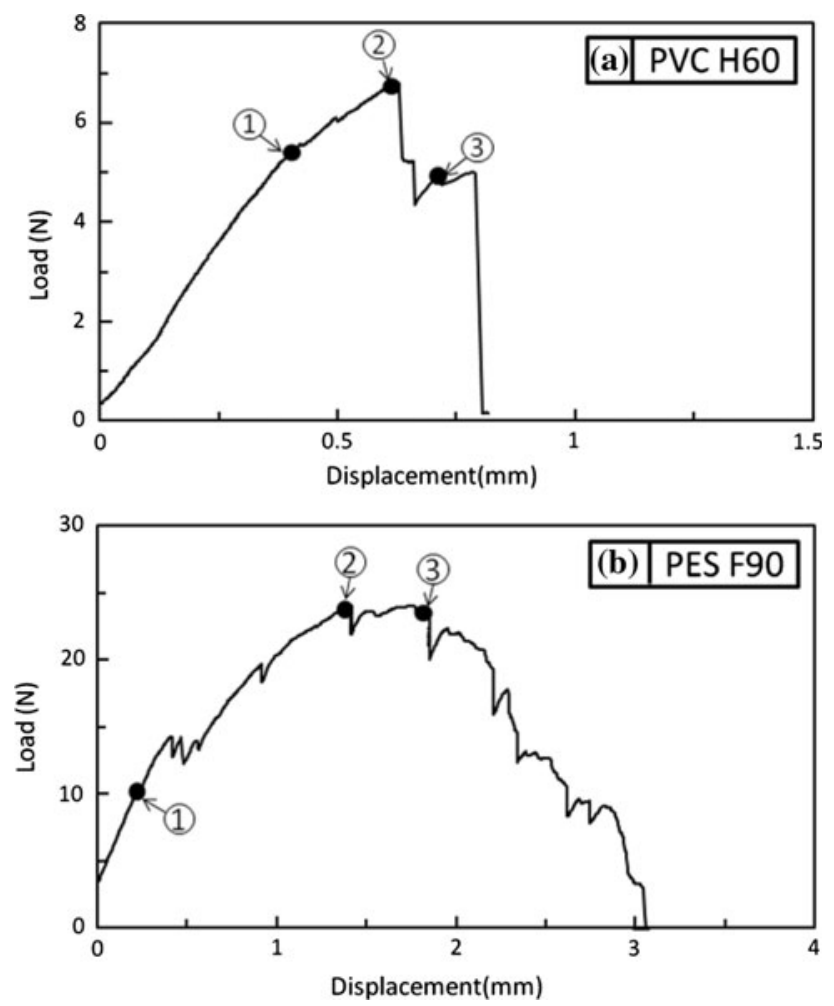

Fig. 7 Load-displacement curves for in situ SEN specimens. a PVC and $\mathbf{b}$ PES

loading, Fig. 9b, the new crack tip position (indicated by an unfilled arrow) shows that the crack has extended about two cells. Interestingly, local damage (FPZ), as indicated by the filled arrows, is observed around the crack tip in six to eight cells in front of the crack tip and four cells above and below the crack tip. As the same specimen is further loaded ( $\approx 6 \mathrm{~N}$ ), Fig. 10a, the crack extended about six to eight cells. This indicates how the new increment of crack
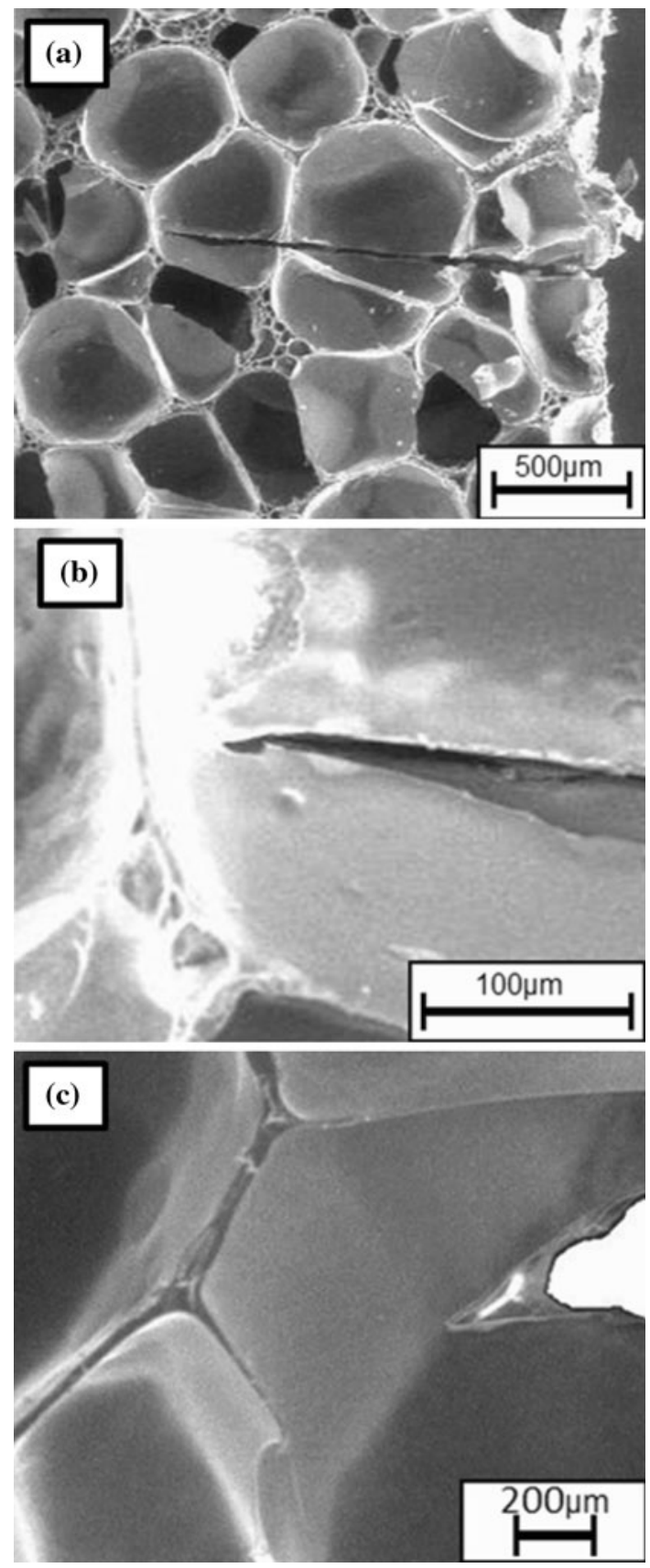

Fig. 8 In situ micrographs of PVC (H60) foams showing a precracked specimen, $\mathbf{b}$ precracked specimen at high magnification, and c tearing of initial precrack 

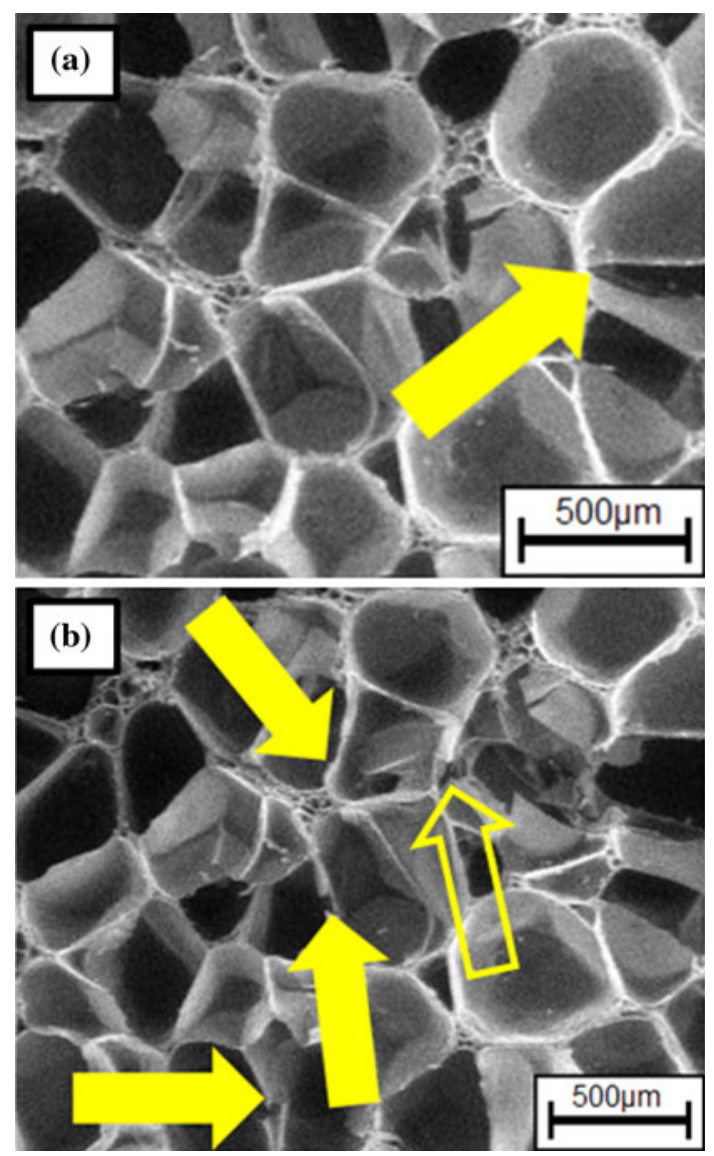

Fig. 9 In situ micrographs of PVC (H60) foams showing a crack extension \# 1, (Fig. 7a) and b crack extension \# 2, (Fig. 7a)

growth is linked to the fracture process zone ahead of the crack tip. Figure 10b and c show the final fracture surfaces of the PVC foam. It appears as the crack tends to propagate in the region between the cells where cell size distribution varies heavily. A region with large variation of cell distribution is shown in Fig. 11. This observation indicates that the presence of small cells at ordinary cell junctions is not a desired property of the foam. These regions of weakness were identified out by Gibson and Ashby [10] in an unspecified polymer foam, and in closed cell aluminum foam by Sugimura et al. [13] who categorized these regions as imperfections that decrease strength of the foam. Overall, based on the in situ SEM observation of the fracture process of this brittle PVC foam it appears that the foam fails predominantly by stretching of the inter-cell material in front of the crack tip.

The corresponding set of in situ SEM micrographs of the fracture process in the PES foams are shown in Figs. 12, 13. Figure 12a shows the precrack in an unloaded PES specimen at low magnification (note that the white line was drawn over the actual position of the crack to show the crack tip position). Figure $12 \mathrm{~b}$ shows the precrack at high magnification after a small load application $(\approx 10 \mathrm{~N}$ in
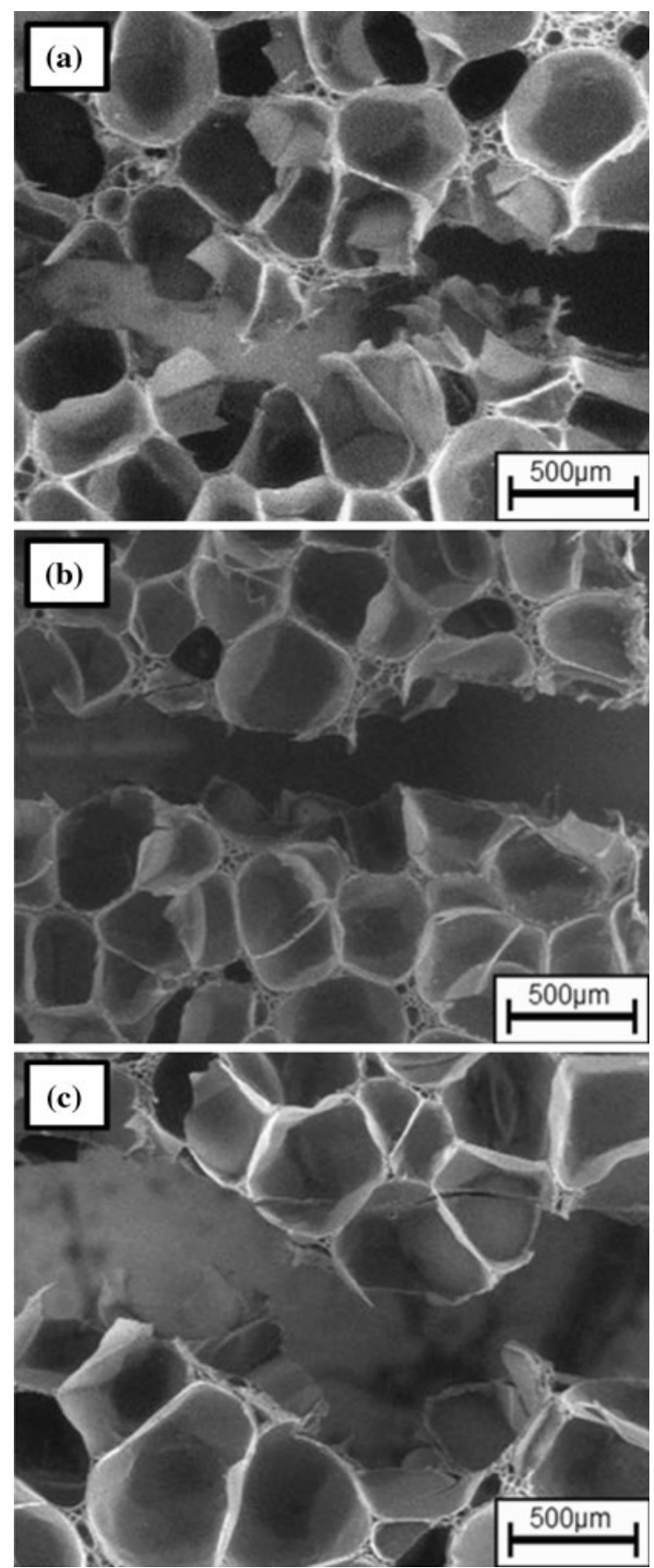

Fig. 10 In situ micrographs of PVC (H60) foams showing a crack extension \# 3, (Fig. 7a), b fracture surface, and $\mathbf{c}$ fracture surface

Fig. 7b) where the initial crack tip is in the vicinity of a cell edge. Further addition of small load application, the crack tip blunts after which crack extension occurs, see Fig. 13a. The rectangular zoomed region of Fig. 13a shown in Fig. 13b, reveals craze-like deformation bands in the highly strained blunted region in front of the crack tip. Figure 14a shows a low magnification micrograph of the crack propagation path with an unfilled arrow indicating the location of the crack tip in the PES foam (No. 2 in Fig. $7 b)$. Figure $14 \mathrm{~b}$ shows the same specimen after further 


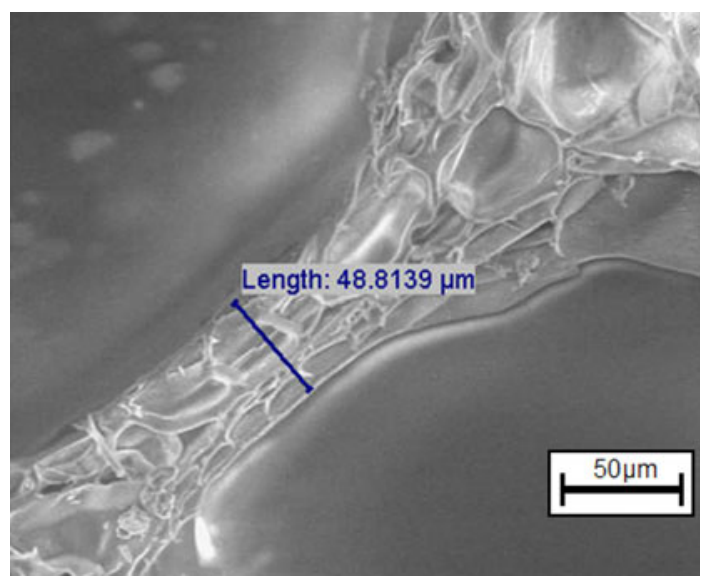

Fig. 11 In situ micrographs of PVC (H60) foams showing highly varying cell size distribution
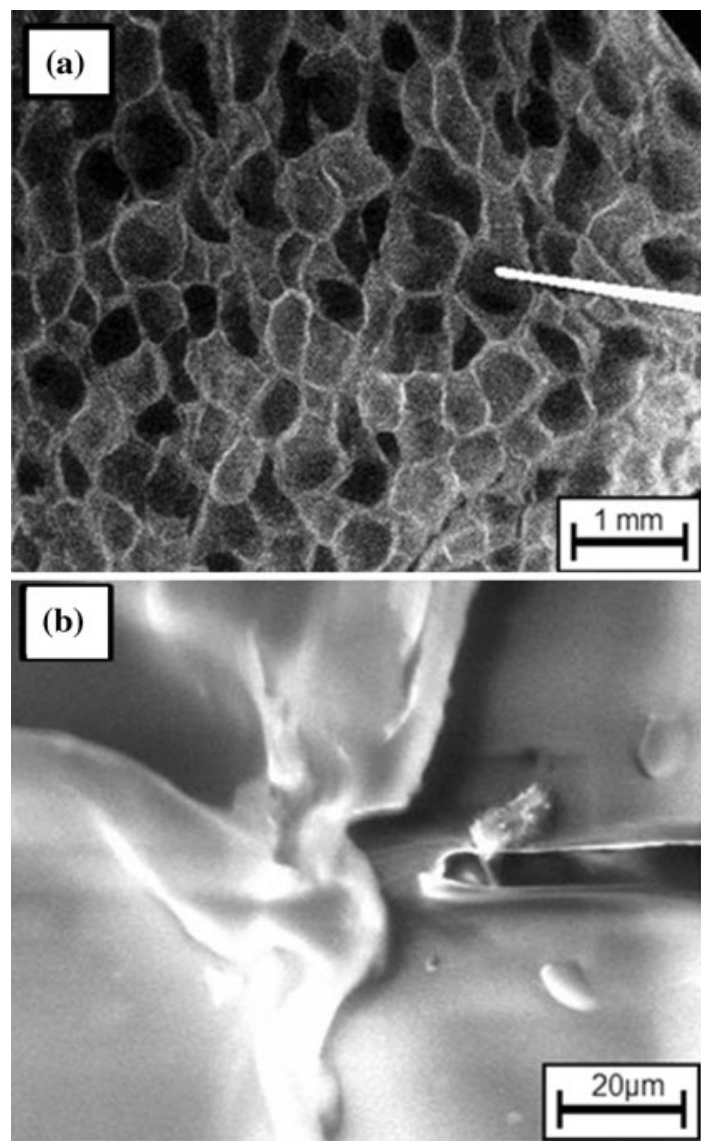

Fig. 12 In situ micrographs of PES (F90) foams. a precracked specimen and b slightly loaded precracked specimen at high magnification

load application with an unfilled arrow showing the new crack tip location (No. 3 in Fig. 7b). Highly deformed cells are observed in front of the crack tip, as indicated by the filled arrows, but no clear indication of cell rupture in the crack tip region was noted. These highly stretched cells
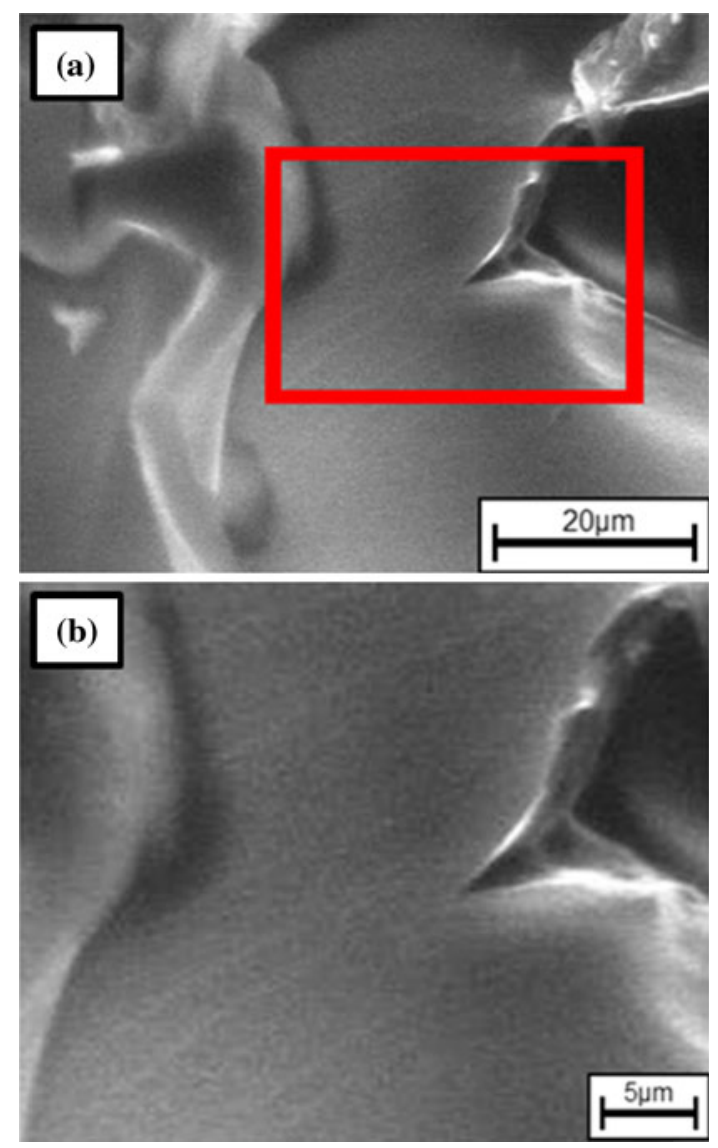

Fig. 13 In situ micrographs of PES (F90) foams. a crack tip blunting and extension and $\mathbf{b}$ craze-band formation ahead of crack tip

eventually rupture upon further loading to increase the initial crack length by about eight cells as indicated by the unfilled arrow in Fig. 14c. Figure 15 shows detail of the fracture surfaces of the PES foam. The crack traveled through the center of the cells as opposed to the boundary between cells as observed in the PVC foam. For both the PVC and PES foams, failure was governed by stretching of the cell walls and edges as opposed to bending of the edges.

\section{Conclusions}

The in situ fracture examination of brittle PVC and ductile PES foams has revealed several important micro-mechanisms. Overall, it appears that the cells in both foams failed in a stretching mode of deformation rather than the cell edge bending mechanism proposed by Maiti et al. [1]. This is attributed to the 3D randomness of the foam structure, which presents more redundancy of the load path than in 2D open cell foam and reduces local bending deformation of the cell edges. The crack in the PVC foam propagated in the region between the larger cells consisting of an 

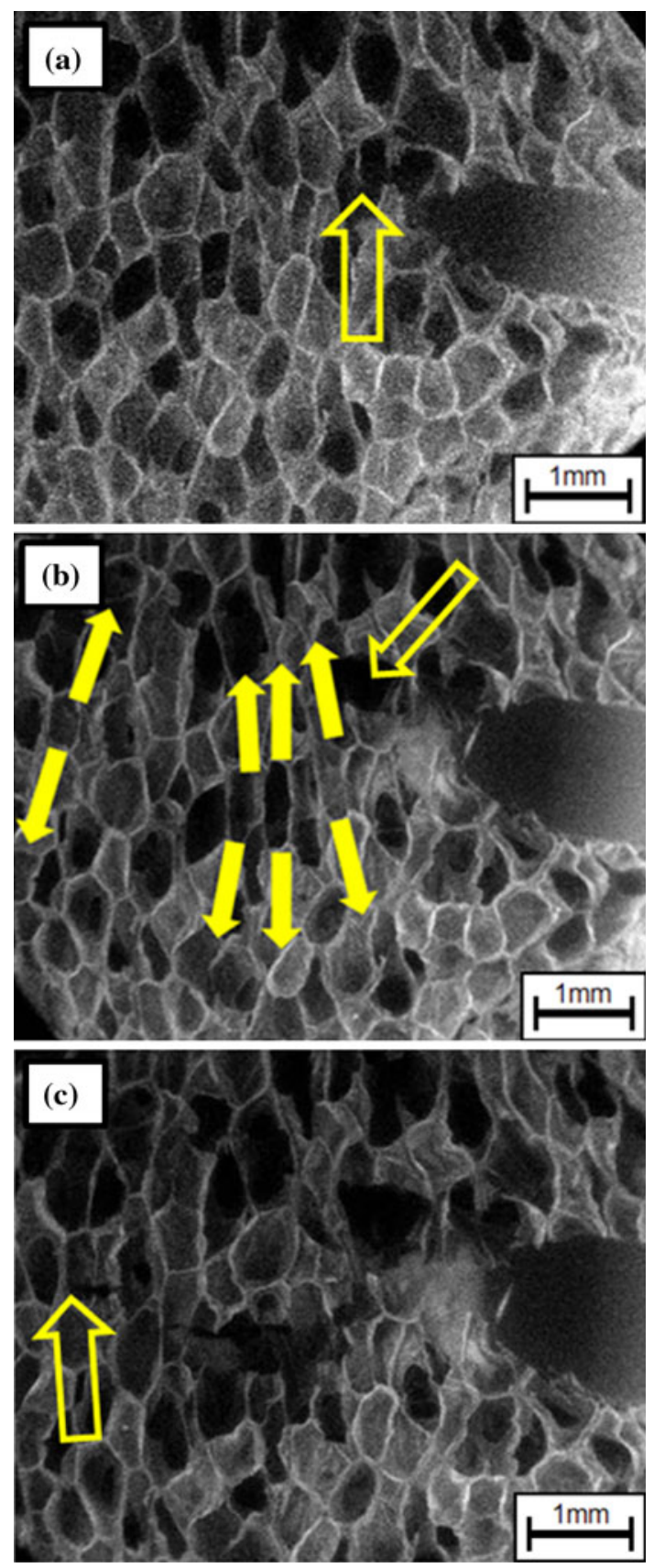

Fig. 14 In situ micrographs of PES (F90) foams. a crack extension \#2, (Fig. 7b), b highly extended foam cells ahead of crack tip \#3, (Fig. 7b), and c crack extension by cell rupture

agglomerate of very small cells, apparently a zone of weakness. Damaged cells were observed above and below the main crack in the PVC foam. Fracture of the PES foam revealed crack tip blunting. Craze-like deformation bands were observed in the cell wall material in front of the

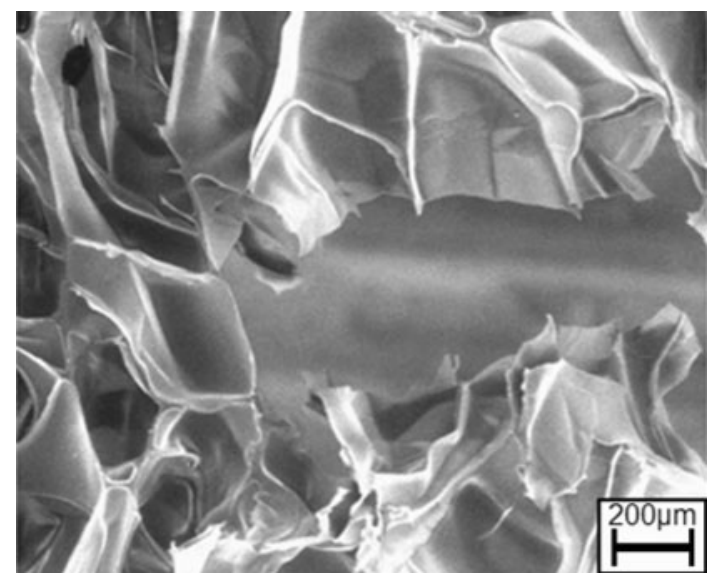

Fig. 15 In situ micrographs of PES (F90) foam showing the final fracture surface

blunted crack tip. Fracture occurred predominantly through the center of the cells by failure of highly deformed cells stretched in the direction of loading.

Acknowledgements Support for this research was provided by the National Science Foundation (\#630105-6) under a sub-contract from University of Delaware. Also, special thanks goes to Chris Kilbourn and James Jones of DIAB Desoto, Texas who provided foam materials free of charge.

\section{References}

1. Maiti S, Ashby MF, Gibson LJ (1984) Scr Metall 18:213

2. Choi S, Sankar B (2005) Int J Solids Struct 42:1797

3. Zenkert D, Bäcklund J (1989) Compos Sci Technol 34(3):225

4. Viana GM, Carlsson LA (2002) J Sandw Struct Mater 4(2):99

5. Motz C, Pippan R (2002) Acta Mater 50(8):2013

6. Saenz E, Carlsson LA, Karlsson AM (2011) J Mater Sci 46(9):3207. doi:10.1007/s10853-010-5205-x

7. Kinloch AJ, Young RJ (1985) Fracture behavior polymers. Elsevier Applied Science Publishers, London

8. ASTM D1622-03 Standard test method for apparent density of rigid cellular plastics

9. ASTM D3576-04 Standard test method for cell size of rigid cellular plastics

10. Gibson LJ, Ashby MF (1988) Cellular solids structure and properties, 1st edn. Pergamon Press, Cambridge

11. Ultrason 1010 PES: Product Information (2004) BASF. http:// worldaccount.basf.com/wa/EU/Catalog/ePlastics/info/BASF/ product/ultrason_e_1010. Accessed August 2009

12. Torlon Polyamide-imide Design Guide (2009) Solvay Advanced Polymers. http://www.solvayadvancedpolymers.com/static/wma/ pdf/9/9/7/Torlon_Design_Guide.pdf. Accessed August 2009

13. Sugimura Y, Meyer J, He M, Bart-Smith H, Grenstedt J, Evans AG (1997) Acta Mater 45(12):5245 